\title{
ANALISIS KEPUASAN KONSUMEN TERHADAP JASA TRANSPORTASI BRT TRANS MUSI KOTA PALEMBANG
}

\author{
HERRY WIDAGDO \\ herry@stie-mdp.ac.id \\ FARADILA MEIRISA \\ faradilameirisa@stie-mdp.ac.id
}

DOI: $\underline{\text { http://dx.doi.org/10.32524/jkb.v16i2.372 }}$

\begin{abstract}
This research has a purpose to analyze consumer satisfaction of BRT Trans Musi transportation service users in Palembang City. Consumer satisfaction was measured through the quality of services provided by BRT Trans Musi consisting of tangible, empaty, responsiveness, reliability and assurance. This type of research is quantitative descriptive research with data collection through questionnaires distributed to BRT Trans Musi transportation service users. The sampling technique was carried out used purposive sampling with a total samples of 200 respondents using the BRT Trans Musi Palembang transportation service. The analysis of this research used multiple linear regression with the results of the research showed tangible, empathy, responsiveness, reliability and assurance simultaneously very influential on consumer satisfaction of BRT Trans Musi Palembang service in the amount of 48,550. The most dominant variable of service quality influential was Tangible of 5,623 while the empaty variable had no effect with a value of 0,801. This research had a determinant coefficient of $54.4 \%$. Keywords: BRT Trans Musi, Service Quality, Consumer Satisfaction
\end{abstract}

\begin{abstract}
Abstraksi
Penelitian ini bertujuan untuk menganalisis kepuasan konsumen pengguna jasa transportasi BRT Trans Musi di Kota Palembang. Kepuasan konsumen diukur melalui kualitas layanan yang diberikan BRT Trans Musi terdiri dari tangible, empaty, responsiveness, reliability dan assurance. Jenis penelitian ini adalah penelitian deskriptif kuantitatif dengan pengumpulan data melalui pembagian kuisioner yang dibagikan kepada pengguna jasa transportasi BRT Trans Musi. Teknik pengambilan sampel dilakukan menggunakan purposive sampling dengan jumlah sampel sebanyak 200 responden pengguna jasa transportasi BRT Trans Musi Palembang. Analisis penelitian ini menggunakan regresi linear berganda dengan hasil penelitian menunjukkan tangible, empaty, responsiveness, reliability dan assurance secara simultan sangat berpengaruh terhadap kepuasan konsumen pengguna jasa BRT Trans Musi Palembang sebesar 48,550. Variabel dari kualitas layanan yang paling dominan berpengaruh adalah Tangible sebesar 5,623 sedangkan variabel empaty tidak berpengaruh dengan nilai 0,801 . Pada penelitian ini memiliki koefisien determinan sebesar 54,4\%.
\end{abstract}

Kata kunci :BRT Trans Musi, Kualitas Layanan, Kepuasan Konsumen 


\section{PENDAHULUAN}

Kota Palembang terkenal sebagai kota industri dan kota perdagangan. Kota Palembang sekarang bukan hanya terkenal sebagai kota industri dan kota perdagangan tetapi juga sebagai kota pariwisata di pulau Sumatera membuat kota Palembang banyak dikunjungi oleh turis domestik maupun luar negeri. Untuk menunjang pariwisata dan perdagangan di kota Palembang transportasi menjadi sorotan utama. Jasa transportasi pada saat ini merupakan suatu sarana yang sangat dibutuhkan bagi kehidupan masyarakat. Masyarakat akan menggunakan kendaraan pribadi atau kendaraan angkutan umum guna mengantarkannya dirinya ke tujuan.

Pemerintah kota Palembang membuat terobosan baru dalam transportasi perkotaan dengan membentuk Bus Rapid Transit (BRT) Trans Musi untuk menggantikan sistem transportasi umum dalam kota sebelumnya. Trans Musi adalah salah satu moda transportasi publik yang beroperasi di kota Palembang. Trans Musi merupakan armada angkutan yang paling popular dibanding dengan moda transportasi di kota Palembang. Trans Musi beroperasi sejak tahun 2009 dengan 20 armada bus medium. BRT Trans Musi dikelola oleh PT.Sarana Pembangunan Palembang Jaya melalui unit usaha BRT Trans Musi yang merupakan perusahaan BUMD. BRT Trans Musi ini hanya melayani dua koridor. Koridor I dari terminal alang-alang lebar melewati simpang polda Sumsel dan berakhir dibawah jembatan ampera dan koridor II dari terminal Sako melewati simpang polda Sumsel dan berakhir di Palembang Indah Mall. Pada tahun 2010 perusahaan menambah 60 bus. Dengan adanya tambahan armada, rute yang dilayani Trans Musi bertambah menjadi 5 koridor.

BRT Trans Musi menyediakan layanan angkutan umum yang disesuaikan dengan kebutuhan masyarakat, pemanfaatan jaringan jalan secara optimal sehingga mengurangi kemacetan lalu lintas, menarik pengguna kendaraan pribadi sehingga menggunakan angkutan umum. Trans Musi memberikan jaminan keamanan yang lebih baik kepada penggunanya, karena dilengkapi dengan pintu keluar masuk yang hanya dibuka/ditutup oleh pengemudi. Setiap harinya, rata-rata Trans Musi mengangkut penumpang sebanyak 15.000 orang. Ketika hari libur atau minggu mengangkut hingga 17.000 penumpang. Pemerintah kota Palembang berharap BRT Trans Musi ini dapat menjadi moda transportasi yang dapat memenuhi kebutuhan dan keinginan dan pada akhirnya diharapkan dapat memuaskan masyarakat kota Palembang.

Faktor utama yang perlu diperhatikan setelah layanan dalam usaha jasa adalah mengenai fasilitas. Fasilitas dalam usaha jasa harus selalu diperhatikan terutama yang berhubungan atau berkaitan erat dengan apa yang dirasakan oleh pengguna jasa atau konsumen. Karena dalam usaha jasa penilaian konsumen terhadap suatu perusahaan didasari atas apa yang mereka peroleh setelah penggunaan jasa tersebut. Menurut Kotler \& Armstrong (2012), nilai pelanggan adalah perbandingan pelanggan antara semua keuntungan dan semua biaya yang harus dikeluarkan untuk menerima penawaran yang diberikan. Karena kepuasan pelanggan sangat tergantung pada persepsi dan ekspektasi pelanggan, maka sebagai pemasok produk perlu mengetahui faktor-faktor yang mempengaruhinya. Kemungkinan antara ekspektasi pelanggan dan kualitas pelayanan (jasa) yang diterimanya adalah pelanggan menjadi senang jika kualitas pelayanan yang 
diterima lebih baik dari perkiraannya. Menurut Kotler dan Keller (2012) terdapat lima faktor dominan atau penentu kualitas pelayanan jasa,yaitu tangible, empaty, responsiveness, reliability dan assurance. Menurut Kotler (2012) mengemukakan bahwa kualitas adalah keseluruhan ciri serta sifat dari suatu produk atau pelayanan yang berpengaruh pada kemampuannya untuk memuaskan kebutuhan yang dinyatakan atau tersirat. Menurut Kotler dan Keller (2009) kepuasan (satisfaction) adalah perasaan senang atau kecewa seseorang yang timbul karena membandingkan kinerja yang telah dipersepsikan produk (atau hasil) terhadap ekspektasi mereka. Kualitas layanan sangat penting bagi perusahaan untuk dapat memenangkan persaingan karena itu sebuah perusahaan jasa dapat memenangkan persaingan dengan menyampaikan secara konsisten layanan yang berkualitas tinggi dibandingkan para pesaing dan yang lebih tinggi dari pada harapan sehingga pada akhirnya dapat memuaskan pengguna atau konsumen.

Berdasarkan latar belakang di atas penulis dapat merumuskan masalah penelitian ini menjadi sebagai berikut:

1. Bagaimana pengaruh variabel tangible, empaty, responsiveness, reliability dan assurance secara Parsial terhadap kepuasan konsumen pada jasa transpotasi BRT Trans Musi Palembang

2. Bagaimana pengaruh variabel tangible, empaty, responsiveness, reliability dan assurance secara Simultan terhadap kepuasan konsumen pada jasa transpotasi BRT Trans Musi Palembang

\section{TELAAH TEORITIS DAN PENGEMBANGAN HIPOTESIS Jasa}

Menurut Kotler dan Keller (2012) jasa adalah setiap aktifitas, manfaat atau performance yang ditawarkan oleh satu pihak ke pihak lain yang bersifat intangible dan tidak menyebabkan perpindahan kepemilikan apapun dimana dalam produksinya dapat terikat maupun tidak dengan produk fisik.

Jasa mempunyai empat karakteristik berbeda yang sangat mempengaeruhi program pemasaran yaitu tak berwujud (intangibility), tak terpisahkan (inseparability), bervariasi (variability) dan dapat musnah (perishability)

1. Tak berwujud (Intangibility), tidak seperti produk fisik, jasa tidak dapat dilihat, dirasakan, diraba, disengar, atau dibaui sebelum jasa itu dibeli. Perusahaan jasa dapat berusaha mendemonstrasikan kualitas jasa mereka melalui bukti fisik dan presentasi. Pemasar jasa harus dapat memstransformasikan jasa tak berwujud ke dalam manfaat konkret dan pengalaman yang terdefinisi dengan baik.

2. Tak terpisahkan (Inseparability), sementara barang fisik dibuat, dimasukkan dalam persediaan, didistribusikan melalui berbagai perantara dan dikonsumsi sekaligus. Jika seorang memberikan jasa, maka penyedia menjadi bagian dari jasa itu. Karena konsumen juga sering hadir ketika jasa itu dibuat, interaksi penyedia - konsumen merupakan fitur khusus dalam pemasaran jasa.

3. Bervariasi (Variability), karena kualitas jasa tergantung pada siapa yang menyediakan, kapan dan dimana dan kepada siapa, jasa sangat bervariasi. Pembeli jasa menyadari variabilitas ini dan sering membicarakannya dengan orang lain sebelum memilih penyedia jasa. Untuk menyakinkan pelanggan, 
beberapa perusahaan menawarkan garansi jasa yang dapat mengurangi presepsi konsumen tentang resiko.

4. Dapat musnah (Perishability), jasa tidak dapat disimpan, jadi dapat musnahnya jasa bisa menjadi masalah ketika permintaan berfluktuasi. Contohnya perusahaan transportasi public harus memiliki peralatan yang jauh lebih banyak karena permintaan pada jam sibuk dan bukan untuk permintaan yang merata sepanjang hari.

Jasa yang diberikan harus mempunyai kualitas yang baik sehingga dapat memenuhi kebutuhan, keinginan dan pada akhirnya dapat memuaskan konsumen. Menurut Tjiptono (2011) kualitas pelayanan jasa adalah tingkat keunggulan yang diharapkan dan pengendalian atas tingkat keunggulan tersebut untuk memenuhi keinginan pelanggan. Dengan kata lain ada dua faktor utama yang mempengaruhi kualitas pelayanan jasa yaitu dirasakan expectedservice danperceived service. Apabila jasa yang diterima atau dirasakan (perceived service) sesuai dengan yang diharapkan, maka kualitas pelayanan jasa di persepsikan baik dan memuaskan. Jika jasa yang diterima melampaui harapan pelanggan, maka kualitas pelayanan jasa di persepsikan sebagai kualitas yang ideal. Sebaliknya, jika jasa diterima lebih rendah daripada yang diharapkan maka kualitas pelayanan jasa di persepsikan buruk.

\section{Kualitas Pelayanan}

Kualitas pelayanan adalah tingkat keunggulan yang diharapkan dan pengendalian atas tingkat keunggulan tersebut untuk memenuhi keinginan pelanggan (Tjiptono, 2011). Pelayanan merupakan perilaku produsen dalam rangka memenuhi kebutuhan dan keinginan konsumen demi tercapainya kepuasan pada konsumen itu sendiri.

Menurut Kotler dan Keller (2012) terdapat lima faktor dominan atau penentu kualitas kualitas pelayanan jasa, terdiri dari:

1. Berwujud (Tangible), yaitu berupa penampilan fisik, peralatan dan berbagai materi komunikasi yang baik.

2. Empati (Empathy), yaitu kesediaan karyawan dan pengusaha untuk lebih peduli memberikan perhatian secara pribadi kepada pelanggan. Misalnya karyawan harus mencoba menempatkan diri sebagai pelanggan. Jika pelanggan mengeluh maka harus dicari solusi segera, agar selalu terjaga hubungan harmonis, dengan menunjukan rasa peduli yang tulus. Dengan cara perhatian yang diberikan para pegawai dalam melayani dan memberikan tanggapan atas keluhan para konsumen.

3. Cepat tanggap (Responsiveness), yaitu kemauan dari karyawan dan pengusaha untuk membantu pelanggan dan memberikan jasa dengan cepat serta mendengar dan mengatasi keluhan konsumen. Dengan cara keinginan para pegawai dalam membantu dan memberikan pelayanan dengan tanggap, kemampuan memberikan pelayanan dengan cepat dan benar, kesigapan para pegawai untuk ramah pada setiap konsumen, kesigapan para pegawai untuk bekerja sama dengan konsumen.

4. Keandalan (Reliability), yaitu kemampuan untuk memberikan jasa sesuai dengan yang dijanjikan, terpercaya dan akurat, serta konsisten. Contoh dalam hal ini antara lain, kemampuan pegawai dalam memberikan pelayanan yang 
terbaik, kemampuan pegawai dalam menangani kebutuhan konsumen dengan cepat dan benar, kemampuan perusahaan dalam memberikan pelayanan yang baik sesuai dengan harapan konsumen.

5. Kepastian (Assurance), yaitu berupa kemampuan karyawan untuk menimbulkan keyakinan dan kepercayaan terhadap janji yang telah dikemukakan kepada konsumen. Contoh dalam hal ini antara lain, pengetahuan dan keterampilan pegawai dalam menjalankan tugasnya, pegawai dapat diandalkan, pegawai dapat memberikan kepercayaan kepada konsumen, pegawai memiliki keahlian teknis yang baik.

\section{Kepuasan Konsumen}

Kepuasan konsumen merupakan sikap, penilaian dan respon emosional yang ditunjukkan oleh konsumen setelah proses pembelian/konsumsi yang berasal dari perbandingan kesannya terhadap kinerja aktual terhadap suatu produk dan harapannya, serta evaluasi terhadap pengalaman mengkonsumsi suatu produk dan jasa. Menurut Kotler dan Keller (2009) kepuasan (satisfaction) adalah perasaan senang atau kecewa seseorang yang timbul karena membandingkan kinerja yang telah dipersepsikan produk (atau hasil) terhadap ekspektasi mereka. Jika kinerja gagal memenuhi ekspektasi, konsumen akan tidak puas. Jika kinerja sesuai dengan ekspektasi, konsumen akan puas. Jika kinerja melebihi ekspektasi, konsumen akan sangat puas atau senang. Perusahaan akan bertindak bijaksana dengan mengukur kepuasan konsumen secara teratur karena salah satu kunci untuk mempertahankan pelanggan adalah kepuasan konsumen.

Menurut Tjiptono (2011) ada beberapa metode yang dipergunakan setiap perusahaan untuk mengukur dan memantau kepuasan konsumen dan konsumen pesaing. Metode untuk mengukur kepuasan pelanggan, antara lain :

1. Sistem Keluhan dan Saran, perusahaan yang berorientasi pada pelanggan akan memberikan kesempatan yang luas pada para pelanggannya untuk menyampaikan saran dan keluhan, misalnya dengan menyediakan kotak saran, kartu komentar dan lain-lain. Informasi dari para pelanggan ini akan memberikan masukan dan ide-ide bagi perusahaan agar bereaksi dengan tanggap dan cepat dalam menghadapi masalah yang timbul. Sehingga perusahaan akan tahu apa yang dikeluhkan oleh para pelanggannya dan segera memperbaikinya. Metode ini berfokus pada identifikasi masalah dan juga pengumpulan saran-saran dari pelanggannya langsung.

2. Ghost Shopping (Mystery Shopping), salah satu cara memperoleh gambaran mengenai kepuasan pelanggan adalah dengan mempekerjakan beberapa orang ghost shopers untuk berperan atau berpura-pura sebagai pelanggan potensial. Sebagai pembeli potensial terhadap produk dari perusahaan dan juga dari produk pesaing. Kemudian mereka akan melaporkan temuan-temuannya mengenai kekuatan dan kelemahan dari produk perusahaan dan pesaing berdasarkan pengalaman mereka dalam pembelian produk- produk tersebut. Selain itu para ghost shopper juga bisa mengamati cara penanganan terhadap setiap keluhan yang ada, baik oleh perusahaan yang bersangkutan maupun dari pesaingnya.

3. Lost Customer Analysis, perusahaan akan menghubungi para pelanggannya atau setidaknya mencari tahu pelanggannya yang telah berhenti membeli 
produk atau yang telah pindah pemasok, agar dapat memahami penyebab mengapa pelanggan tersebut berpindah ke tempat lain. Dengan adanya peningkatan customer lost rate, di mana peningkatan customer lost rate menunjukkan kegagalan perusahaan dalam memuskan pelanggannya.

4. Survei Kepuasan Pelanggan, sebagian besar riset kepuasan pelanggan dilakukan dengan menggunakan metode survei, baik survei melalui pos, telepon, e-mail, website, maupun wawancara langsung. Melalui survei perusahaan akan memperoleh tanggapan dan balikan secara langsung (feedback) dari pelanggan dan juga akan memberikan kesan positif terhadap para pelanggannya.

Kerangka pemikiran akan menjelaskan secara teoritis pertautan antara variabel yang akan diteliti. Jadi secara teoritis perlu dijelaskan hubungan antara variabel independen dan dependen.Penelitian ini membahas tentang Pengaruh kualitas pelayanan (tangible, empaty, responsiveness, reliability dan assurance) terhadap Kepuasan Pelanggan BRT Trans Musi Palembang secara parsial dan simultan.Gambar kerangka pemikiran penelitian ini dapat dilihat pada Gambar 1.

\section{Gambar 1 \\ Kerangka Pemikiran}

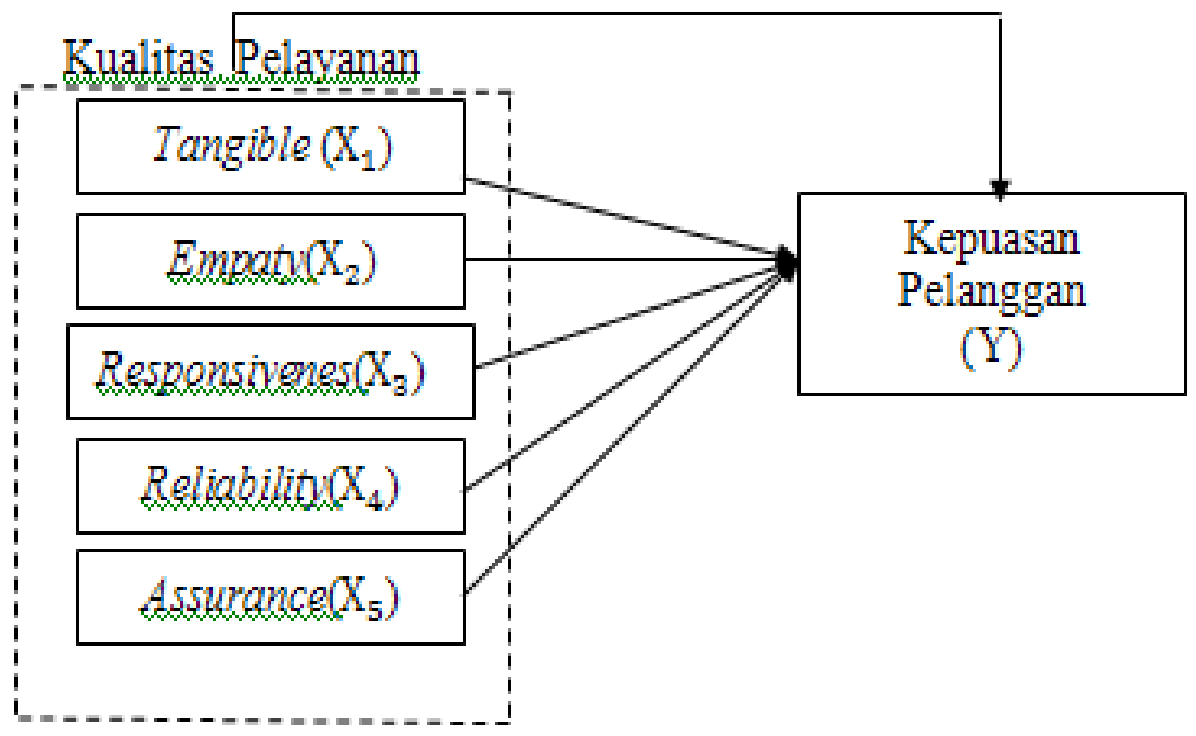

\section{Hipotesis Penelitian}

$\mathrm{Ho}_{1}$ : Variabel tangible, tidak berpengaruh terhadap kepuasan konsumen pada jasa transpotasi BRT Trans Musi Palembang

$\mathrm{Ha}_{1}$ : Variabel tangible berpengaruh terhadap kepuasan konsumen pada jasa transpotasi BRT Trans Musi Palembang

$\mathrm{Ho}_{2}$ : Variabel empaty, tidak berpengaruh terhadap kepuasan konsumen pada jasa transpotasi BRT Trans Musi Palembang

$\mathrm{Ha}_{2}$ : Variabel empaty berpengaruh terhadap kepuasan konsumen pada jasa transpotasi BRT Trans Musi Palembang 
$\mathrm{Ho}_{3}$ : Variabel responsivenes, tidak berpengaruh terhadap kepuasan konsumen pada jasa transpotasi BRT Trans Musi Palembang

$\mathrm{Ha}_{3}$ : Variabel responsivenes berpengaruh terhadap kepuasan konsumen pada jasa transpotasi BRT Trans Musi Palembang

$\mathrm{Ho}_{4}$ : Variabel reliability, tidak berpengaruh terhadap kepuasan konsumen pada jasa transpotasi BRT Trans Musi Palembang

$\mathrm{Ha}_{4}$ : Variabel reliability berpengaruh terhadap kepuasan konsumen pada jasa transpotasi BRT Trans Musi Palembang

$\mathrm{Ho}_{5}$ : Variabel assurance tidak berpengaruh terhadap kepuasan konsumen pada jasa transpotasi BRT Trans Musi Palembang

$\mathrm{Ha}_{5}$ : Variabel assurance berpengaruh terhadap kepuasan konsumen pada jasa transpotasi BRT Trans Musi Palembang

$\mathrm{Ho}_{6}$ : Variabel tangible, empaty, responsiveness, reliability dan assurance tidak berpengaruh Secara Simultan terhadap kepuasan konsumen pada jasa transpotasi BRT Trans Musi Palembang

$\mathrm{Ha}_{6}$ : Variabel tangible, empaty, responsiveness, reliability dan assurance berpengaruh Secara Simultan terhadap kepuasan konsumen pada jasa transpotasi BRT Trans Musi Palembang

\section{METODE PENELITIAN}

Jenis penelitian ini adalah penelitian kuantitatif deskriptif yaitu penelitian yang dilakukan dengan melakukan penggambaran atau pemaparan tentang variabel-variabel yang diteliti dan mencoba untuk menarik kesimpulan. Penelitian ini dilakukan di kota Palembang

Menurut Sugiyono (2013), populasi adalah wilayah generalisasi terdiri atas objek atau subjek yang mempunyai kualitas dan karakteristik tertentu. Diterapkan oleh penelitian untuk dipelajari dan kemudian ditarik kesimpulannya. Populasi yang akan diteliti adalah masyarakat kota Palembang yang yang menggunakan jasa transportasi BRT Trans Musi Palembang

Sampel adalah sebagian dari jumlah dan karakteristik yang di miliki oleh populasi tersebut (Sugiyono,2013). Teknik pengambilan sampel bersifat purposive sampling. Sampling merupakan teknik non probabilitik sampling yang memilih orang-orang terseleksi oleh peneliti berdasarkan ciri-ciri khusus yang dimiliki sample tersebut yang dipandang mempunyai sangkut paut yang erat dengan ciri-ciri khusus atau sifat populasi yang sudah diketahui sebelumnya. Untuk pengambilan sampel sebagaimana dalam metode-metode statistik lainnya menghasilkan dasar untuk mengestimasi kesalahan sampling. Hair et. al (1998), menemukan bahwa ukuran sampel yang sesuai adalah antara 100-200 sampel. Pada penelitian ini diambil sampel sebanyak 200 responden yang sudah menggunakan jasa BRT Trans Musi Palembang.

\section{Definisi Operasional Variabel}

Menurut Sugiyono (2010) mendefinisikan variabel penelitian adalah segala sesuatu yang berbentuk apa saja yang ditetapkan oleh peneliti untuk dipelajari sehingga diperoleh informasi tentang hal tersebut, kemudian ditarik kesimpulannya.Variabel penelitian terdiri atas variabel independendan variabel dependen. Adapun variabel dalam penelitian ini dapat diuraikan sebagai berikut : 
1. Variabel Dependen

Variabel dependen adalah variabel yang menjadi pusat perhatian penelitian. Variabel dependen yaitu variabel yang nilainya tergantung dari variabel lain, dimana nilainya akan berubah jika variabel yang mempengaruhinya berubah. Variabel dependen sering pula disebut variabel respon yang dilambangkan dengan Y. Variabel dependen dalam penelitian ini adalah Kepuasan Pelanggan (Y).

2. Variabel Independen

Variabel independen adalah variabel yang mempengaruhi variabel dependen, baik yang pengaruhnya positif maupun yang pengaruhnya negatif. Variabel independen sering disebut predikator yang dilambangkan dengan $\mathrm{X}$. Variabel independen dalam penelitian ini adalah :Tangible $\left(\mathrm{X}_{1}\right)$, Empathy $\left(\mathrm{X}_{2}\right)$, Responsiveness $\left(\mathrm{X}_{3}\right)$, Reliability) $\left(\mathrm{X}_{4}\right)$ dan Assurance $\left(\mathrm{X}_{5}\right)$.

Tabel 1

Variabel Penelitian dan Definisi Operasional

\begin{tabular}{|c|c|c|c|}
\hline $\begin{array}{c}\text { Variabel } \\
\text { Penelitian }\end{array}$ & Definisi & Indikator & Skala \\
\hline $\begin{array}{l}\text { Kepuasan } \\
\text { (Y) }\end{array}$ & $\begin{array}{l}\text { Kepuasan (satisfaction) } \\
\text { adalah perasaan senang atau } \\
\text { kecewa seseorang yang } \\
\text { timbul karena } \\
\text { membandingkan kinerja yang } \\
\text { telah dipersepsikan produk } \\
\text { (atau hasil) terhadap } \\
\text { ekspektasi mereka } \\
\text { (Kotler dan Keller, 2009) }\end{array}$ & $\begin{array}{l}\text { 1. Membeli lagi } \\
\text { 2. Mengatakan hal-hal } \\
\text { baiktentang } \\
\text { perusahaan dan } \\
\text { merekomendasikan } \\
\text { nya } \\
\text { 3. Kurang } \\
\text { memperhatikan } \\
\text { merek dan iklan } \\
\text { produk pesaing } \\
\text { 4. Membeli produk } \\
\text { lain dari perusahaan } \\
\text { yang sama. } \\
\text { 5. Menawarkan ide } \\
\text { produk atau jasa } \\
\text { kepada perusahaan }\end{array}$ & Ordinal \\
\hline $\begin{array}{l}\text { Tangible } \\
\qquad\left(\mathrm{X}_{1}\right)\end{array}$ & $\begin{array}{l}\text { Tangible yaitu berupa } \\
\text { penampilan fisik, peralatan } \\
\text { dan berbagai materi } \\
\text { komunikasi yang baik. } \\
\text { (Kotler dan Keller, 2012) }\end{array}$ & $\begin{array}{l}\text { 1. Peralatan modern } \\
\text { 2. Fasilitas yang } \\
\text { berdaya tarik } \\
\text { visual } \\
\text { 3. Karyawan yang } \\
\text { berpenampilan rapi } \\
\text { dan profesional } \\
\text { 4. Materi-materi } \\
\text { berkaitan dengan } \\
\text { jasa yang berdaya } \\
\text { tarik visual }\end{array}$ & Ordinal \\
\hline
\end{tabular}




\begin{tabular}{|c|c|c|c|}
\hline \multirow[t]{2}{*}{$\begin{array}{l}\text { Empathy } \\
\qquad\left(\mathrm{X}_{2}\right)\end{array}$} & $\begin{array}{l}\text { Empathy yaitu } r \text { kesediaan } \\
\text { karyawan dan pengusaha } \\
\text { untuk lebih } \text { peduli } \\
\text { memberikan perhatian secara } \\
\text { pribadi kepada pelanggan. } \\
\text { (Kotler dan Keller, 2012) }\end{array}$ & $\begin{array}{l}\text { 1. Memberikan } \\
\text { perhatian secara } \\
\text { individual kepada } \\
\text { para pelanggan } \\
\text { 2. Karyawan yang } \\
\text { memperlakukan } \\
\text { pelanggan secara } \\
\text { penuh perhatian } \\
\text { 3. Sungguh-sungguh } \\
\text { mengutamakan } \\
\text { kepentingan } \\
\text { pelanggan }\end{array}$ & \multirow[t]{2}{*}{ Ordinal } \\
\hline & & $\begin{array}{l}\text { 4. Karyawan yang } \\
\text { memahami } \\
\text { kebutuhan } \\
\text { pelanggan } \\
\text { 5. Waktu beroperasi } \\
\text { yang nyaman }\end{array}$ & \\
\hline $\begin{array}{l}\text { Responsiveness } \\
\left(\mathrm{X}_{3}\right)\end{array}$ & $\begin{array}{l}\text { Responsiveness yaitu } \\
\text { kemauan dari karyawan dan } \\
\text { pengusaha untuk membantu } \\
\text { pelanggan dan memberikan } \\
\text { jasa dengan cepat serta } \\
\text { mendengar dan mengatasi } \\
\text { keluhan konsumen. } \\
\text { (Kotler dan Keller, 2012) }\end{array}$ & $\begin{array}{l}\text { 1. Menginformasikan } \\
\text { pelanggan tentang } \\
\text { kepastian waktu } \\
\text { penyampaian jasa } \\
\text { 2. Layanan yang } \\
\text { segera/ cepat bagi } \\
\text { pelanggan } \\
\text { 3. Kesediaan untuk } \\
\text { membantu } \\
\text { pelanggan } \\
\text { 4. Kesiapan untuk } \\
\text { merespon } \\
\text { permintaan } \\
\text { pelanggan }\end{array}$ & Ordinal \\
\hline $\begin{array}{l}\text { Reliability } \\
\quad\left(\mathrm{X}_{4}\right)\end{array}$ & $\begin{array}{l}\text { Reliability yaitu kemampuan } \\
\text { untuk memberikan jasa sesuai } \\
\text { dengan yang dijanjikan, } \\
\text { terpercaya dan akurat, serta } \\
\text { konsisten.(Kotler dan Keller, } \\
\text { 2012) }\end{array}$ & $\begin{array}{l}\text { 1. Menyediakan jasa } \\
\text { sesuai yang } \\
\text { dijanjikan } \\
\text { 2. Dapat diandalkan } \\
\text { dalam menangani } \\
\text { masalah jasa } \\
\text { pelanggan } \\
\text { 3. Menyampaikan } \\
\text { jasa secara benar } \\
\text { semenjak pertama } \\
\text { kali } \\
\text { 4. Menyampaikan } \\
\text { jasa sesuai dengan } \\
\text { waktu yang }\end{array}$ & Ordinal \\
\hline
\end{tabular}


dijanjikan

5. Menyimpan

catatan/ dokumen

tanpa kesalahan

$\begin{array}{cl} & \text { Assurance yaitu berupa } \\ & \text { kemampuan karyawan untuk } \\ & \text { menimbulkan keyakinan dan } \\ & \text { kepercayaan terhadap janji } \\ & \text { yang telah dikemukakan } \\ & \text { kepada konsumen. (Kotler } \\ & \text { dan Keller, 2012) }\end{array}$

1. Menumbuhkan

rasa percaya para

pelanggan

2. Membuat

pelanggan merasa

aman sewaktu

melakukan

transaksi

Ordinal

3. Karyawan secara

konsisten bersikap

sopan

4. Karyawan yang

mampu menjawab

pertanyaan

pelanggan

\section{Sumber Data}

Sumber data pada penelitian meliputi adalah sebagai berikut:

1. Data primer

Data primer merupakan sumber pertama baik dari individu atau perorangan yang didapat atau dikumpulkan oleh peneliti dengan cara langsung dari sumbernya dengan data asli atau data baru melalui observasi, diskusi terfokus, wawancara serta penyebaran kuesioner. Data primer dalam penelitian ini adalah membagikan kuesioner pada masyarakat pengguna BRT Trans Musi Palembang

2. Data Sekunder

Sumber data sekunder merupakan data yang diperoleh atau dikumpulkan dan disatukan oleh studi-studi sebelumnya atau yang diterbitkan oleh berbagai instansi lain. Data sekunder pada penelitian ini diperoleh dari manajemen BRT Trans Musi Palembang.

\section{Teknik Analisis Data}

\section{Uji Validitas dan Reliabilitas}

Menurut Sugiyono (2012) mengemukakan tentang perbedaan hasil penelitian yang valid dan reliabel dengan instrument yang valid dan reliable "hasil penelitian yang valid bila terdapat kesamaan antara data yang terkumpul dengan data yang sesungguhnya terjadi pada objek yang diteliti. Hasil penelitian yang reliabel, bila terdapat kesamaan data dalam waktu yang berbeda. Sedangkan instrumen yang valid berarti alat ukur yang digunakan mendapatkan data (mengukur) itu valid. Selanjutnya instrument yang reliabel adalah instrument yang bila digunakan beberapa kali untuk mengukur obyek yang sama, akan menghasilkan data yang sama". Jadi dengan menggunakan instrument yang valid 
dan reliabel dalam pengumpulan data, maka akan menghasilkan penelitian yang valid dan reliabel. Validitas instrument menggunakan rumus korelasi product moment untuk variabel $\mathrm{X}$ dan $\mathrm{Y}$ (Sugiyono,2012):

$$
r_{x y}=\frac{N X Y-\left(\sum X\right)\left(\sum Y\right)}{\left\{N \sum X^{2}-\left(\sum X\right)^{2}\right\}\left\{N \sum Y^{2}-\left(\sum Y\right)^{2}\right\}}
$$

Keterangan :

$\mathrm{r}_{\mathrm{xy}}=$ koefisien antara $\mathrm{X}$ dan $\mathrm{Y}$

$\mathrm{N}=$ jumlah responden

$\mathrm{X}=$ jumlah skor item

$\mathrm{Y}=$ jumlah skor total

\section{Uji Normalitas}

Uji normalitas digunakan untuk menguji apakah dalam sebuah model regresi variabel dependen dan variabel independen atau keduanya mempunyai data distribusi normal atau tidak. Model regresi yang baik adalah distribusi normal atau mendekati normal.Pengujian dilakukan dengan Uji Kolmogorov smirnov yang dilakukan terhadap data residual model regresi. Intepretasinya adalah jika nilainya diatas 0,05 maka distribusi data dinyatakan memenuhi asumsi normalitas, dan jika nilainya dibawah 0,05 maka diinterpretasikan sebagai tidak normal.

\section{Uji Multikolinearitas}

Uji Multikolinearitas bertujuan untuk menguji apakah pada model regresi ditemukan adanya kolerasi antar variabel-variabel bebas. Suatu regresi yang baik yaitu model regresi yang tidak terjadi multikolonieritas, artinya antara variabel independen yang satu dengan yang lain dalam model regresi tidak saling berhubungan secara sempurna.

Dalam penelitian ini, teknik yang digunakan adalah melihat nilai dari variance inflation factor (VIF) dan nilai tolerance. Kedua ukuran ini menunjukan setiap variabel independen mana saja yang dijelaskan oleh variabel independen lainnya. Jika nilai tolerance lebih dari atau sama dengan $10 \%(\geq 0,10)$ dan nilai variance inflation factor kurang dari atau sama dengan $10(\leq 10)$, maka tidak terjadi multikolonieritas.

\section{Uji Heteroskedastisitas}

Uji Heteroskedastisitas adalah uji yang bertujuan untuk menguji apakah dalam model regresi terjadi ketidaksamaan variance dari residual satu pengamatan ke pengamatan lain. Jika variance dari residual satu pengamatan ke pengamatan yang lain tetap, maka disebut homoskedastisitas dan jika berbeda disebut heterokedastisitas. Model regresi yang baik adalah yang homoskedastisitas atau tidak terjadi heterokedastisitas. Uji heterokedastisitas dapat dilihat dengan grafik plot (scatterplot) di mana penyebaran titik-titik yang ditimbulkan terbentuk secara acak, tidak membentuk sebuah pola tertentu serta arah penyebarannya berada di atas maupun di bawah angka 0 pada sumbu Y. Dengan demikian tidak terjadi gejala heterokedastisitas pada regresi ini, sehingga model regresi yang dilakukan layak dipakai. 


\section{Uji F}

Uji $\mathrm{F}$ adalah pengujian terhadap koefisien regresi secara simultan.Pengujian uji ini dilakukan untuk mengetahui pengaruh semua variabel independen yang terdapat di dalam model secara bersama-sama (simultan) terhadap variabel dependen. Uji $\mathrm{F}$ dalam penelitian ini digunakan untuk menguji signifikansi pengaruh current ratio, debt ratio, total assets turn over, return on assets terhadap keputusan investasi aktiva tetap secara simultan. Rumus pengujian adalah sebagai berikut

Keterangan :

$$
F=\quad \frac{R^{2} / k}{\left(1-R^{2}\right) /(n-k-1)}
$$

$R^{2}=$ Koefisien determinasi

$k=$ Jumlah variabel independen

$n=$ Jumlah data atau kasus

$F$ hasil perhitungan ini dibandingkan dengan $F_{\text {tabel }}$ yang diperoleh dengan menggunakan tingkat resiko atau signifikan level 5\% atau dengan degree freedom $=n-k-1$ dengan kriteria sebagai berikut:

Ho ditolak jika $\mathrm{F}_{\text {hitung }}>\mathrm{F}_{\text {tabel }}$

Ho diterima jika $\mathrm{F}_{\text {hitung }}<\mathrm{F}_{\text {tabel }}$

Jika terjadi penerimaan Ho, maka dapat diartikan sebagai tidak signifikannya model regresi berganda yang diperoleh sehingga mengakibatkan tidak signifikan pula pengaruh dari variabel-variabel bebas secara simultan terhadap variabel terikat.

\section{Uji t}

Uji $t$ berarti melakukan pengujian terhadap koefisien regresi secara parsial. Pengujian ini dilakukan untuk mengetahui signifikansi peran secara parsial antara variabel independen terhadap variabel dependen dengan mengasumsikan bahwa variabel independen lain dianggap konstan. Sugiyono (2010) merumuskan uji $t$ sebagai berikut:

$$
t=\frac{r \sqrt{n-2}}{\sqrt{1-r^{2}}}
$$

Keterangan:

$\mathrm{t}=$ Distribusi $\mathrm{t}$

$\mathrm{n}=$ Jumlah data

$\mathrm{r}=$ Koefisien korelasi parsial

$r^{2}=$ Koefisien determinasi

Hasil perhitungan ini selanjutnya dibandingkan dengan $t_{\text {table }}$ dengan menggunakan tingkat kesalahan 0,05 . Kriteria yang digunakan sebagai dasar perbandingan sebagai berikut :

Ho diterima jika nilai $-\mathrm{t}_{\text {table }}<\mathrm{t}_{\text {hitung }}<\mathrm{t}_{\text {table }}$

Ho ditolak jika nilai $t_{\text {hitung }}>t_{\text {table }}$ atau $t_{\text {hitung }}<-t_{\text {table }}$

Bila terjadi penerimaan Ho maka dapat disimpulkan suatu pengaruh adalah tidak signifikan, sedangkan bila Ho ditolak artinya suatu pengaruh adalah signifikan. 


\section{Regresi Linier Berganda}

Analisis regresi linier berganda menurut Sugiyono (2010), "Analisis yang digunakan peneliti, bila bermaksud meramalkan bagaimana keadaan (naik turunnya) variabel dependen (kriterium), bila dua atau lebih variabel independen sebagai faktor prediktor dimanipulasi (dinaik turunkan nilainya).

Persamaan regresi untuk penelitian ini dapat dirumuskan sebagai berikut:

$\mathrm{Y}=\mathrm{a}+\mathrm{b}_{1} \mathrm{X}_{1}+\mathrm{b}_{2} \mathrm{X}_{2}+\mathrm{b}_{3} \mathrm{X}_{3}+\mathrm{b}_{4} \mathrm{X}_{4}+\mathrm{b}_{5} \mathrm{X}_{5}+\mathrm{e}$

Keterangan:

$\mathrm{Y}=$ variabel terikat (dependent) Kepuasan

$\mathrm{X}_{1}=$ variabel bebas (independent) Tangible $\left(\mathrm{X}_{1}\right)$

$\mathrm{X}_{2}=$ variabel bebas (independent) Empathy $\left(\mathrm{X}_{2}\right)$

$\mathrm{X}_{3}=$ variabel bebas (independent) Responsiveness $\left(\mathrm{X}_{3}\right)$

$\mathrm{X}_{4}=$ variabel bebas (independent) Reliability) $\left(\mathrm{X}_{4}\right)$

$\mathrm{X}_{5}=$ variabel bebas (independent) Assurance $\left(\mathrm{X}_{5}\right)$.

$\mathrm{a}=$ nilai konstanta.

$\mathrm{b}=$ koefisien regresi.

$\mathrm{e}=$ error

\section{HASIL DAN PEMBAHASAN}

Tabulasi Data Responden dan Analisis Data

Responden Berdasarkan Umur

Umur responden dibagi menjadi 4 (empat) kategori dan dapat dilihat pada Tabel 2 Umur Responden.

Tabel 2

Umur Responden

\begin{tabular}{ccc}
\hline Kategori Umur & Jumlah Responden & Persentase \\
\hline $12-21$ th & 52 & $26 \%$ \\
\hline $22-31$ th & 75 & $37,50 \%$ \\
\hline $32-41$ th & 49 & $24,50 \%$ \\
\hline$>42$ th & 24 & $12 \%$ \\
\hline Total & $\mathbf{2 0 0}$ & $\mathbf{1 0 0 \%}$ \\
\hline
\end{tabular}

Dari Tabel 2 Kategori Umur Responden dapat dilihat yang menggunakan jasa transportasi BRT Trans Musi Palembang paling banyak dilakukan pada kategori umur 22-31 tahun sebanyak 84 orang atau sebesar $51 \%$ diikuti kategori umur 32-41 tahun sebanyak 42 orang atau 42\% lalu kategori umur 12-21 tahun sebanyak 28 orang atau $17 \%$ dan kategori umur $>41$ tahun sebanyak 11 orang atau sebesar $7 \%$ dari jumlah keseluruhan responden.

\section{Responden Berdasarkan Jenis Kelamin}

Jenis Kelamin responden dibagi menjadi 2 (dua) kategori dan dapat dilihat pada Tabel 3 Jenis Kelamin Responden. 
Tabel 3

Kategori Jenis Kelamin Responden

\begin{tabular}{lll}
\hline $\begin{array}{c}\text { Kategori } \\
\text { Jenis Kelamin }\end{array}$ & \multicolumn{1}{c}{$\begin{array}{c}\text { Jumlah } \\
\text { Responden }\end{array}$} & Persentase \\
\hline Pria & 85 & $42,50 \%$ \\
\hline Wanita & 115 & $57,50 \%$ \\
\hline Total & $\mathbf{2 0 0}$ & $\mathbf{1 0 0 \%}$ \\
\hline
\end{tabular}

Dari Tabel 3 Kategori Jenis Kelamin Responden dapat dilihat yang menggunakan jasa transportasi BRT Trans Musi Palembang paling banyak dilakukan pada kategori jenis kelamin wanita sebanyak 86 orang atau sebesar $57 \%$ dan kategori jenis kelamin pria sebanyak 64 orang atau $43 \%$ dari jumlah keseluruhan responden.

\section{Responden Berdasarkan Pendidikan}

Pendidikan responden dibagi menjadi 4 (empat) kategori dan dapat dilihat pada Tabel 4 Pendidikan Responden.

\section{Tabel 4}

Kategori Pendidikan Responden

\begin{tabular}{lcc}
\hline $\begin{array}{c}\text { Kategori } \\
\text { Pendidikan }\end{array}$ & $\begin{array}{c}\text { Jumlah } \\
\text { Responden }\end{array}$ & Persentase \\
\hline SMP & 25 & $12,50 \%$ \\
\hline SMA & 94 & $47 \%$ \\
\hline S1 & 52 & $26 \%$ \\
\hline Lainnya & 29 & $14,50 \%$ \\
\hline Total & $\mathbf{2 0 0}$ & $\mathbf{1 0 0 \%}$ \\
\hline
\end{tabular}

Dari Tabel 4 Kategori Pendidikan Responden dapat dilihat yang menggunakan jasa transportasi BRT Trans Musi Palembang paling banyak dilakukan pada kategori pendidikan SMA sebanyak 70 orang atau sebesar $47 \%$ diikuti kategori pendidikan S1 sebanyak 48 orang atau $32 \%$ lalu kategori pendidikan SMP sebanyak 27 orang atau 18\% dan kategori pendidikan lainnya sebanyak 5 orang atau sebesar 3\% dari jumlah keseluruhan responden.

\section{Responden Berdasarkan Pekerjaan}

Pekerjaan responden dibagi menjadi 4 (empat) kategori dan dapat dilihat pada Tabel 5 Pekerjaan Responden.

Tabel 5

Kategori Pekerjaan Responden

\begin{tabular}{lcc}
\hline Kategori Pekerjaan & $\begin{array}{c}\text { Jumlah } \\
\text { Responden }\end{array}$ & Persentase \\
\hline Pelajar/Mahasiswa & 34 & $17 \%$ \\
\hline Wiraswasta & 49 & $24,50 \%$ \\
\hline Karyawan & 84 & $42 \%$ \\
\hline Lainnya & 33 & $16,50 \%$ \\
\hline Total & $\mathbf{2 0 0}$ & $\mathbf{1 0 0 \%}$ \\
\hline
\end{tabular}


Dari Tabel 5 Kategori Pekerjaan Responden dapat dilihat yang menggunakan jasa transportasi BRT Trans Musi Palembang paling banyak dilakukan pada kategori pekerjaan lainnya sebanyak 58 orang atau sebesar 39\% diikuti kategori pekerjaan karyawan sebanyak 38 orang atau 25\% lalu kategori pekerjaanpelajar/mahasiswa sebanyak 36 orang atau $24 \%$ dan kategori pekerjaan wiraswasta sebanyak 18 orang atau sebesar $12 \%$ dari jumlah keseluruhan responden.

\section{Responden Berdasarkan Pengeluaran Perbulan}

Pekerjaan responden dibagi menjadi 4 (empat) kategori dan dapat dilihat pada Tabel 6 Pengeluaran Perbulan Responden.

\section{Tabel 6}

\begin{tabular}{lcc}
\multicolumn{3}{c}{ Kategori Pengeluaran Perbulan Responden } \\
\hline $\begin{array}{c}\text { Kategori } \\
\text { Pengeluaran }\end{array}$ & $\begin{array}{c}\text { Jumlah } \\
\text { Responden }\end{array}$ & Persentase \\
\hline < 1Juta & 49 & $24,50 \%$ \\
\hline 1Juta s/d 3Juta & 73 & $36,50 \%$ \\
\hline 3Juta s/d 5Juta & 50 & $25 \%$ \\
\hline$>$ 5Juta & 28 & $14 \%$ \\
\hline Total & $\mathbf{2 0 0}$ & $\mathbf{1 0 0 \%}$ \\
\hline
\end{tabular}

Dari Tabel 6 Kategori Pengeluaran Perbulan Responden dapat dilihat yang menggunakan jasa transportasi BRT Trans Musi Palembang paling banyak dilakukan pada kategori pengeluaran perbulan 1juta s/d 3juta sebanyak 63 orang atau sebesar $42 \%$ diikuti kategori pengeluaran perbulan < 1juta sebanyak 57 orang atau 38\% lalu kategori pengeluaran perbulan 3juta s/d 5juta sebanyak 25 orang atau $17 \%$ dan kategori pengeluaran perbulan $>5$ juta sebanyak 5 orang atau sebesar 3\% dari jumlah keseluruhan responden.

\section{Analisis Uji Validitas, Reliabilitas dan Normalitas}

\section{Uji Validitas Variabel Tangible}

Dengan pengujian terhadap 200 responden pada signifikasi $5 \%$ maka $r_{\text {tabel }}$ adalah $\mathrm{df}=\mathrm{n}-2=200-2=198(0,1406)$ dan $\mathrm{r}_{\text {hitung }}$ dapat dilihat pada tabel 7 .

Tabel 7

Hasil Uji Validitas Variabel Tangible $\left(\mathrm{X}_{1}\right)$

\begin{tabular}{ccccc}
\hline Variabel & $\begin{array}{c}\text { Item } \\
\text { Pernyataan }\end{array}$ & $\mathbf{r}_{\text {hitung }}$ & $\mathbf{r}_{\text {tabel }}$ & Keterangan \\
\hline \multirow{3}{*}{$\begin{array}{c}\text { Tangible } \\
\left(\mathrm{X}_{1}\right)\end{array}$} & 2 & 0,657 & 0,1406 & Valid \\
\cline { 2 - 5 } & 3 & 0,659 & 0,1406 & Valid \\
\cline { 2 - 5 } & 4 & 0,653 & 0,1406 & Valid \\
\cline { 2 - 5 } & 5 & 0,550 & 0,1406 & Valid \\
\hline
\end{tabular}

Sumber: Hasil Pengolahan Data, 2018 
Berdasarkan Tabel 7 di atas, diketahui bahwa 5 item pernyataan pada tangiblemenghasilkan $r_{\text {hitung }}$ lebih besar dibanding $r_{\text {tabel }} 0,1406$, maka setiap itemitem pernyataan dari variabel tangible dinyatakan valid.

\section{Uji Validitas Variabel Empaty}

Dengan pengujian terhadap 200 responden pada signifikasi $5 \%$ maka $r_{\text {tabel }}$ adalah $\mathrm{df}=\mathrm{n}-2=200-2=198(0,1406)$ dan $\mathrm{r}_{\text {hitung }}$ dapat dilihat pada Tabel 8.

Tabel 8

Hasil Uji Validitas Variabel Empaty $\left(\mathbf{X}_{2}\right)$

\begin{tabular}{ccccc}
\hline Variabel & $\begin{array}{c}\text { Item } \\
\text { Pernyataan }\end{array}$ & $\mathbf{r}_{\text {hitung }}$ & $\mathbf{r}_{\text {tabel }}$ & Keterangan \\
\hline \multirow{3}{*}{$\begin{array}{c}\text { Empaty } \\
\left(\mathrm{X}_{2}\right)\end{array}$} & 2 & 0,752 & 0,1406 & Valid \\
\cline { 2 - 5 } & 3 & 0,636 & 0,1406 & Valid \\
\cline { 2 - 5 } & 4 & 0,584 & 0,1406 & Valid \\
\hline & 5 & 0,654 & 0,1406 & Valid \\
\hline
\end{tabular}

Sumber: Hasil Pengolahan Data, 2018

Pada Tabel 8 diketahui terdapat 5 item pernyataan pada variabel Empatydan memiliki $r_{\text {hitung }}$ lebih besar dibanding $r_{\text {tabel }} 0,1406$, sehingga semua item variabel Empatydikatakan valid.

\section{Uji Validitas Variabel Responsivenes}

Dengan pengujian terhadap 200 responden pada signifikasi $5 \%$ maka $r_{\text {tabel }}$ adalah $\mathrm{df}=\mathrm{n}-2=200-2=198(0,1406)$ dan $\mathrm{r}_{\text {hitung }}$ dapat dilihat pada Tabel 9.

Tabel 9

Hasil Uji Validitas Variabel Responsivenes $\left(\mathbf{X}_{3}\right)$

\begin{tabular}{ccccc}
\hline \multirow{2}{*}{ Variabel } & $\begin{array}{c}\text { Item } \\
\text { Pernyataan }\end{array}$ & $\mathbf{r}_{\text {hitung }}$ & $\mathbf{r}_{\text {tabel }}$ & Keterangan \\
\hline \multirow{3}{*}{$\begin{array}{c}\text { Responsivenes } \\
\left(\mathrm{X}_{3}\right)\end{array}$} & 1 & 0,646 & 0,1406 & Valid \\
\cline { 2 - 5 } & 3 & 0,750 & 0,1406 & Valid \\
\cline { 2 - 5 } & 4 & 0,649 & 0,1406 & Valid \\
\hline
\end{tabular}

Sumber: Hasil Pengolahan Data, 2018

Pada Tabel 9 diketahui terdapat 4 item pernyataan pada variabel Responsivenes dan memiliki $r_{\text {hitung }}$ lebih besar dibanding $r_{\text {tabel }} 0,1406$, sehingga semua item variabel Responsivenes dikatakan valid.

\section{Uji Validitas Variabel Reliability}

Dengan pengujian terhadap 200 responden pada signifikasi $5 \%$ maka $r_{\text {tabel }}$ adalah df= n-2 =200-2=198 $(0,1406)$ dan $r_{\text {hitung }}$ dapat dilihat pada tabel 10 . 
Tabel 10

Hasil Uji Validitas Variabel Reliability $\left(\mathbf{X}_{4}\right)$

\begin{tabular}{ccccc}
\hline Variabel & $\begin{array}{c}\text { Item } \\
\text { Pernyataan }\end{array}$ & $\mathbf{r}_{\text {hitung }}$ & $\mathbf{r}_{\text {tabel }}$ & Keterangan \\
\hline \multirow{3}{*}{$\begin{array}{c}\text { Reliability } \\
\left(\mathrm{X}_{4}\right)\end{array}$} & 2 & 0,631 & 0,1406 & Valid \\
\cline { 2 - 5 } & 3 & 0,617 & 0,1406 & Valid \\
\cline { 2 - 5 } & 4 & 0,591 & 0,1406 & Valid \\
\hline & 5 & 0,678 & 0,1406 & Valid \\
\hline
\end{tabular}

Sumber: Hasil Pengolahan Data, 2018

Pada Tabel 10 diketahui terdapat 5 item pernyataan pada variabel Reliabilitydan memiliki $r_{\text {hitung }}$ lebih besar dibanding $r_{\text {tabel }} 0,1406$, sehingga semua item variabel Reliability dikatakan valid.

\section{Uji Validitas Variabel Assurance}

Dengan pengujian terhadap 200 responden pada signifikasi $5 \%$ maka $r_{\text {tabel }}$ adalah $\mathrm{df}=\mathrm{n}-2=200-2=198(0,1406)$ dan $\mathrm{r}_{\text {hitung }}$ dapat dilihat pada Tabel 11.

Tabel 11

Hasil Uji Validitas Variabel Assurance $\left(\mathbf{X}_{5}\right)$

\begin{tabular}{ccccc}
\hline Variabel & $\begin{array}{c}\text { Item } \\
\text { Pernyataan }\end{array}$ & $\mathbf{r}_{\text {hitung }}$ & $\mathbf{r}_{\text {tabel }}$ & Keterangan \\
\hline \multirow{3}{*}{$\begin{array}{c}\text { Assurance } \\
\left(\mathrm{X}_{5}\right)\end{array}$} & 1 & 0,718 & 0,1406 & Valid \\
\cline { 2 - 5 } & 2 & 0,675 & 0,1406 & Valid \\
\cline { 2 - 5 } & 3 & 0,677 & 0,1406 & Valid \\
\hline
\end{tabular}

Sumber: Hasil Pengolahan Data, 2018

Pada Tabel 11 diketahui terdapat 4 item pernyataan pada variabel Assurancedan memiliki $r_{\text {hitung }}$ lebih besar dibanding $r_{\text {tabel }} 0,1406$, sehingga semua item variabel Assurancedikatakan valid.

\section{Uji Validitas Variabel Kepuasan}

Dengan pengujian terhadap 200 responden pada signifikasi 5\% maka $r_{\text {tabel }}$ adalah $\mathrm{df}=\mathrm{n}-2=200-2=198(0,1406)$ dan $\mathrm{r}_{\text {hitung }}$ dapat dilihat pada Tabel 12.

Tabel 12

Hasil Uji Validitas Variabel Kepuasan (Y)

\begin{tabular}{ccccc}
\hline \multirow{2}{*}{ Variabel } & $\begin{array}{c}\text { Item } \\
\text { Pernyataan }\end{array}$ & $\mathbf{r}_{\text {hitung }}$ & $\mathbf{r}_{\text {tabel }}$ & Keterangan \\
\hline \multirow{3}{*}{$\begin{array}{c}\text { Kepuasan } \\
(Y)\end{array}$} & 2 & 0,720 & 0,1406 & Valid \\
\cline { 2 - 5 } & 3 & 0,585 & 0,1406 & Valid \\
\cline { 2 - 5 } & 4 & 0,713 & 0,1406 & Valid \\
\cline { 2 - 5 } & 5 & 0,585 & 0,1406 & Valid \\
\hline
\end{tabular}

Sumber: Hasil Pengolahan Data, 2018 
Berdasarkan Tabel 12 terdapat 5 item pernyataan pada variabel Kepuasan yang memiliki $r_{\text {hitung }}$ lebih besar dibandingkan $r_{\text {tabel }}$ 0,1406, sehingga semua item yang variabel Kepuasan dikatakan valid.

\section{Uji Reliabilitas Variabel Tangible}

Teknik yang akan digunakan dalam penelitian ini adalah teknik koefisien korelasi Alpha Cronbach dengan nilai signifikasi lebih besar dari 0,6 maka dapat dikatakan penelitian tersebut reliabel. Hasil Uji Reliabilitas Variabel Tangible dapat dilihat pada Tabel 13.

Tabel 13

Hasil Uji Reliabilitas Variabel Tangible $\left(\mathbf{X}_{1}\right)$

\begin{tabular}{ccc}
\hline Variabel & Alpha Cronbch & Keterangan \\
\hline Tangible $\left(\mathrm{X}_{1}\right)$ & 0,601 & Reliabel \\
\hline Sumber: Hasil Pengolahan Data, 2018 &
\end{tabular}

Dari Tabel 13 hasil uji reliabilitas di atas dapat diketahui bahwa nilai alpha Cronbach untuk variabel Tangible $\left(\mathrm{X}_{1}\right)$ sebesar 0,601 lebih besar dari 0,6 Artinya instrumen ini hasilnya reliabel sehingga dapat dipercaya.

\section{Uji Reliabilitas Variabel Empaty}

Teknik yang akan digunakan dalam penelitian ini adalah teknik koefisien korelasi Alpha Cronbach dengan nilai signifikasi lebih besar dari 0,6 maka dapat dikatakan penelitian tersebut reliabel. Hasil Uji Reliabilitas Variabel Empaty dapat dilihat pada Tabel 14.

Tabel 14

Hasil Uji Reliabilitas Variabel Empaty $\left(\mathbf{X}_{2}\right)$

\begin{tabular}{ccc}
\hline Variabel & Alpha Cronbch & Keterangan \\
\hline Empaty $\left(\mathrm{X}_{2}\right)$ & 0,635 & Reliabel
\end{tabular}

Sumber: Hasil Pengolahan Data, 2018

Dari Tabel 14 hasil uji reliabilitas di atas dapat diketahui bahwa nilai alpha Cronbach untuk variable Empaty $\left(\mathrm{X}_{2}\right)$ sebesar 0,635 lebih besar dari 0,6 Artinya instrumen ini hasilnya reliabel sehingga dapat dipercaya.

\section{Uji Reliabilitas Variabel Responsivenes}

Teknik yang akan digunakan dalam penelitian ini adalah teknik koefisien korelasi Alpha Cronbach dengan nilai signifikasi lebih besar dari 0,6 maka dapat dikatakan penelitian tersebut reliabel. Hasil Uji Reliabilitas Variabel Responsivenes dapat dilihat pada Tabel 15.

Tabel 15

Hasil Uji Reliabilitas Variabel Responsivenes $\left(\mathbf{X}_{3}\right)$

\begin{tabular}{ccc}
\hline Variabel & Alpha Cronbch & Keterangan \\
\hline Responsivenes $\left(\mathrm{X}_{3}\right)$ & 0,602 & Reliabel \\
\hline
\end{tabular}

Sumber: Hasil Pengolahan Data, 2018 
Dari Tabel 15 hasil uji reliabilitas di atas dapat diketahui bahwa nilai alpha Cronbach untuk variable Responsivenes $\left(\mathrm{X}_{3}\right)$ sebesar 0,602 lebih besar dari 0,6 Artinya instrumen ini hasilnya reliabel sehingga dapat dipercaya.

\section{Uji Reliabilitas Variabel Reliability}

Teknik yang akan digunakan dalam penelitian ini adalah teknik koefisien korelasi Alpha Cronbach dengan nilai signifikasi lebih besar dari 0,6 maka dapat dikatakan penelitian tersebut reliabel. Hasil Uji Reliabilitas Variabel Reliability dapat dilihat pada Tabel 16.

\begin{tabular}{ccc} 
Tabel 16 & \\
Hasil Uji Reliabilitas Variabel & Reliability $\left(\mathbf{X}_{\mathbf{4}}\right)$ \\
\hline Variabel & Alpha Cronbch & Keterangan \\
\hline Empaty $\left(\mathrm{X}_{4}\right)$ & 0,624 & Reliabel \\
\hline Sumber: Hasil Pengolahan Data, 2018
\end{tabular}

Dari Tabel 16 hasil uji reliabilitas di atas dapat diketahui bahwa nilai alpha Cronbach untuk variabelReliability $\left(\mathrm{X}_{4}\right)$ sebesar 0,624 lebih besar dari 0,6 Artinya instrumen ini hasilnya reliabel sehingga dapat dipercaya.

\section{Uji Reliabilitas Variabel Assurance}

Teknik yang akan digunakan dalam penelitian ini adalah teknik koefisien korelasi Alpha Cronbach dengan nilai signifikasi lebih besar dari 0,6 maka dapat dikatakan penelitian tersebut reliabel. Hasil Uji Reliabilitas Variabel Assurance dapat dilihat pada Tabel 17.

Tabel 17

Hasil Uji Reliabilitas Variabel Assurance $\left(\mathrm{X}_{5}\right)$

\begin{tabular}{ccc}
\hline Variabel & Alpha Cronbch & Keterangan \\
\hline Assurance $\left(\mathrm{X}_{5}\right)$ & 0,605 & Reliabel \\
\hline
\end{tabular}

Sumber: Hasil Pengolahan Data, 2018

Dari Tabel 17 hasil uji reliabilitas di atas dapat diketahui bahwa nilai alpha Cronbach untuk variable Assurance $\left(\mathrm{X}_{5}\right)$ sebesar 0,605 lebih besar dari 0,6 Artinya instrumen ini hasilnya reliabel sehingga dapat dipercaya.

\section{Uji Reliabilitas Variabel Kepuasan}

Teknik yang akan digunakan dalam penelitian ini adalah teknik koefisien korelasi Alpha Cronbach dengan nilai signifikasi lebih besar dari 0,6 maka dapat dikatakan penelitian tersebut reliabel. Hasil Uji Reliabilitas Variabel Kepuasan dapat dilihat pada Tabel 18.

\section{Tabel 18}

Hasil Uji Reliabilitas Variabel Kepuasan (Y)

\begin{tabular}{ccc}
\hline Variabel & Alpha Cronbch & Keterangan \\
\hline Kepuasan (Y) & 0,692 & Reliabel \\
\hline Sumber: Hasil Pengolahan Data, 2018
\end{tabular}


Dari Tabel 18 hasil uji reliabilitas di atas dapat diketahui bahwa nilai alpha Cronbach untuk variabel Kepuasan (Y) sebesar 0,692 lebih besar dari 0,6 Artinya instrumen ini hasilnya reliabel sehingga dapat dipercaya.

\section{Uji Normalitas}

Hasil pengujian normalitas dengan menggunakan metode One Sample Kolmogorov-Smirnov dapat dilihat dari nilai Unstandarized Residual dengan ketentuan data berdistribusi normal jika signifikan $>0,05$ dan dapat dilihat hasilnya pada Tabel 19.

Tabel 19

Hasil Uji Normalitas

\begin{tabular}{llc}
\hline \multicolumn{2}{c}{ One-Sample Kolmogorov-Smirnov Test } \\
\hline $\mathrm{N}$ & $\begin{array}{c}\text { Unstandardize } \\
\text { d Residual }\end{array}$ \\
Normal Parameters $^{\mathrm{a}}$ & Mean & 200 \\
& Std. Deviation & .0000000 \\
Most Extreme & Absolute & 2.08628825 \\
Differences & Positive & .069 \\
& Negative & .035 \\
Kolmogorov-Smirnov Z & & -.069 \\
Asymp. Sig. (2-tailed) & & .981 \\
\hline a. Test distribution is Normal. & .291 \\
\hline \multicolumn{2}{c}{ Sumber: Hasil Pengolahan Data, 2018 }
\end{tabular}

Dari hasil pengujian normalitas dengan cara Kolmogorov-Smirnov di atas, maka diperoleh hasil bahwa nilai residual terstandarisasi dan dikatakan berdistribusi normal karena nilai asymp. Sig (2-tailed) > 0,05 yaitu 0,291>0,05.

\section{Uji Multikolinearitas}

Hasil pengujian Multikolinearitas dapat dilihat pada Tabel 20

Tabel 20

hasil Uji Multikolinearitas

\begin{tabular}{|c|c|c|c|c|c|c|c|c|}
\hline \multicolumn{9}{|c|}{ Coefficients $^{\mathrm{a}}$} \\
\hline & \multirow{2}{*}{ Model } & \multicolumn{3}{|c|}{$\begin{array}{c}\text { Unstandardized Standardized } \\
\text { Coefficients Coefficients }\end{array}$} & \multirow{2}{*}{$\mathbf{t}$} & \multirow{2}{*}{ Sig. } & \multicolumn{2}{|c|}{$\begin{array}{c}\text { Collinearity } \\
\text { Statistics }\end{array}$} \\
\hline & & B & $\begin{array}{l}\text { Std. } \\
\text { Error }\end{array}$ & Beta & & & $\begin{array}{c}\text { Toleranc } \\
\text { e }\end{array}$ & VIF \\
\hline \multirow[t]{3}{*}{1} & (Constant) & -3.376 & 1.443 & & -2.340 & .020 & & \\
\hline & TANGIBLE & .402 & .071 & .346 & 5.623 & .000 & .605 & 1.652 \\
\hline & EMPATY & .056 & .071 & .050 & .801 & .424 & .593 & 1.685 \\
\hline
\end{tabular}




\begin{tabular}{llllllll}
\hline RESPONSIVE & .293 & .086 & .216 & 3.413 & .001 & .570 & 1.754 \\
RELIABILITY & .189 & .063 & .153 & 2.988 & .003 & .869 & 1.151 \\
ASSURANCE & .345 & .088 & .232 & 3.926 & .000 & .654 & 1.530 \\
\hline
\end{tabular}

a. Dependent Variable: KEPUASAN

Sumber: Hasil Pengolahan Data, 2018

Dari Tabel 20 diatas diperoleh nilai Tolerance variabel tangible $\left(\mathrm{X}_{1}\right)$ yaitu 0,605 lebih besar dari 0,01 dan nilai VIF 1.652 sehingga dapat disimpulkan bahwa tidak terjadi Multikoloniaritas. Nilai Tolerance variabel empaty $\left(\mathrm{X}_{2}\right)$ yaitu 0,593 dan nilai VIF 1.685 sehingga dapat disimpulkan bahwa tidak terjadi Multikolonieritas. Nilai Tolerance variabel responsiveness $\left(\mathrm{X}_{3}\right)$ yaitu 0,570 dan nilai VIF 1.754 sehingga dapat disimpulkan bahwa tidak terjadi Multikolonieritas. Nilai Tolerance variabel reliability $\left(\mathrm{X}_{4}\right)$ yaitu 0,869 dan nilai VIF 1.151 sehingga dapat disimpulkan bahwa tidak terjadi Multikolonieritas dan nilai Tolerance variabel assurance $\left(\mathrm{X}_{5}\right)$ yaitu 0,654 dan nilai VIF 1.530 sehingga dapat disimpulkan bahwa tidak terjadi Multikolonieritas. Dari pembahasan diatas dapat ditarik kesimpulan bahwa model regresi pada penelitian ini tidak mengalami gangguan Multikolinearitas atau tidak terdapat kolerasi antar variabel bebas sehingga model regresi ini layak digunakan.

\section{Uji Heteroskedastisitas}

Hasil pengujian Heteroskedastisitas dapat dilihat pada Gambar 2.

\section{Gambar 2}

\section{Hasil Uji Heteroskedastisitas}

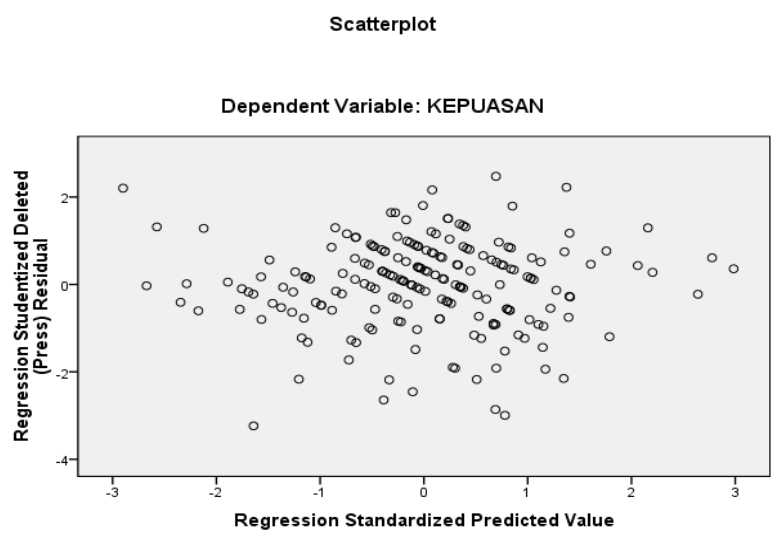

Dilihat dari gambar 2 diatas dapat disimpulkan bahwa model regresi dalam penelitian ini dikatakan bebas dari heteroskedatisitas karena penyebaran residual. Hal tersebut dapat dilihat dari tidak teratur plot yang terpencar serta tidak membentuk suatu pola tertentu. 


\section{Uji Hipotesis}

Uji t

Uji t adalah alat untuk menguji pengaruh secara parsial atau secara individu dari setiap variabel bebas terhadap variabel terikat.

Taraf signifikan menggunakan 0,05,yaitu:

Jika $\mathrm{T}_{\text {hitung }} \leq \mathrm{T}_{\text {tabel }}$, maka $\mathrm{H}_{0}$ diterima dan $\mathrm{H}_{\mathrm{a}}$ ditolak

Jika $\mathrm{T}_{\text {hitung }}>\mathrm{T}_{\text {tabel }}$, maka $\mathrm{H}_{0}$ ditolak dan $\mathrm{H}_{\mathrm{a}}$ diterima Hasil Uji t dari penelitian ini adapat dilihat pada Tabel 21.

\section{Tabel 21}

Hasil Uji t

\begin{tabular}{|c|c|c|c|c|c|}
\hline \multicolumn{6}{|c|}{ Coefficients $^{\mathrm{a}}$} \\
\hline \multirow[b]{2}{*}{ Model } & \multicolumn{2}{|c|}{$\begin{array}{l}\text { Unstandardized } \\
\text { Coefficients }\end{array}$} & \multirow{2}{*}{$\begin{array}{c}\begin{array}{c}\text { Standardized } \\
\text { Coefficients }\end{array} \\
\text { Beta }\end{array}$} & & \multirow[b]{2}{*}{ t Sig. } \\
\hline & B & Std. Error & & & \\
\hline 1 (Constant) & -3.376 & 1.443 & & & $2.340^{-} .020$ \\
\hline TANGIBLE & .402 & .071 & & .346 & 5.623 .000 \\
\hline EMPATY & .056 & .071 & & .050 & .801 .424 \\
\hline RESPONSIVE & .293 & .086 & & .216 & 3.413 .001 \\
\hline RELIABILITY & .189 & .063 & & .153 & 2.988 .003 \\
\hline ASSURANCE & .345 & .088 & & .232 & 3.926 .000 \\
\hline
\end{tabular}

Berdasarkan Tabel di atas dapat disimpulkan sebagai berikut:

a. Variabel Tangible $\left(\mathrm{X}_{1}\right)$ menghasilkan nilai $\mathrm{t}_{\text {hitung }}$ sebesar 5,623 lebih besar dari $t_{\text {tabel }} 1,9720$ dan nilai signifikansi $0,000<0,05$. Dengan demikian dapat disimpulkan bahwa Tangible berpengaruh secara positif dan signifikan terhadap kepuasan jasa BRT Trans Musi Palembang.

b. Variabel Empaty $\left(\mathrm{X}_{2}\right)$ menghasilkan nilai $t_{\text {hitung }}$ sebesar 0,801 lebih kecil dari $\mathrm{t}_{\text {tabel }} 1,9720$ dan nilai signifikansi $0,424>0,05$. Dengan demikian dapat disimpulkan bahwa Empaty tidak berpengaruh secara positif dan tidak signifikan terhadap kepuasan jasa BRT Trans Musi Palembang.

c. Variabel Responsivenes $\left(\mathrm{X}_{3}\right)$ menghasilkan nilai $t_{\text {hitung }}$ sebesar 3,413 lebih besar dari $t_{\text {tabel }} 1,9720$ dan nilai signifikansi $0,001<0,05$. Dengan demikian dapat disimpulkan bahwa Responsivenes berpengaruh secara positif dan signifikan terhadap kepuasan jasa BRT Trans Musi Palembang.

d. Variabel Reliability $\left(\mathrm{X}_{4}\right)$ menghasilkan nilai $\mathrm{t}_{\text {hitung }}$ sebesar 2,988 lebih besar dari $t_{\text {tabel }} 1,9720$ dan nilai signifikansi $0,003<0,05$. Dengan demikian dapat disimpulkan bahwa Reliability berpengaruh secara positif dan signifikan terhadap kepuasan jasa BRT Trans Musi Palembang. 
e. Variabel Assurance (X5) menghasilkan nilai thitung sebesar 3,926 lebih besar dari ttabel 1,9720 dan nilai signifikansi $0,000<0,05$. Dengan demikian dapat disimpulkan bahwa Assurance berpengaruh secara positif dan signifikan terhadap kepuasan jasa BRT Trans Musi Palembang.

f. Variabel yang paling signifikan dan dominan terhadap terhadap kepuasan jasa BRT Trans Musi Palembang adalah variabel Tangible $\left(\mathrm{X}_{1}\right)$, hal ini dapat dilihat dari nilai $t_{\text {hitung }}$ paling besar yaitu 5,623 dan nilai signifikansi 0,000.

\section{Uji F}

Uji F digunakan untuk menguji apakah variabel bebas (independent) secara bersama-sama berpengaruh secara signifikan terhadap variabel terikat (dependent). Taraf signifikan menggunakan 0,05 yaitu;

Jika $\mathrm{F}_{\text {hitung }} \leq \mathrm{F}_{\text {tabel }}$, maka $\mathrm{H}_{0}$ diterima dan $\mathrm{H}_{\mathrm{a}}$ ditolak

Jika $\mathrm{F}_{\text {hitung }}>\mathrm{F}_{\text {tabel }}$, maka $\mathrm{H}_{0}$ ditolak dan $\mathrm{H}_{\mathrm{a}}$ diterima

Tabel 22

Hasil Uji F

\begin{tabular}{lrrrrr}
\hline \multicolumn{6}{c}{ Hasil Uji F $^{c}$} \\
\hline \multicolumn{1}{c}{ ANOVA $^{\mathbf{b}}$} \\
\hline Model & Sum of Squares & df & Mean Square & \multicolumn{1}{c}{ F } & Sig. \\
\hline Regression & 1083.833 & 5 & 216.767 & 48.550 & $.000^{\mathbf{a}}$ \\
Residual & 866.167 & 194 & 4.465 & & \\
Total & 1950.000 & 199 & & & \\
\hline
\end{tabular}

a. Predictors: (Constant), ASSURANCE, RELIABILITY, EMPATY,

TANGIBLE, RESPONSIVE

b. Dependent Variable: KEPUASAN

Sumber: Hasil Pengolahan Data, 2018

Dari tabel di atas dapat dilihat bahwa nilai $\mathrm{f}_{\text {hitung }}$ adalah 48,550 dengan tingkat signifikansi 0,000 . Sedangkan $\mathrm{f}_{\text {tabel }}$ pada alpha 5\% adalah 2,26 dengan nilai : df $1=\mathrm{k}-1=6-1=2$, df $2=\mathrm{n}-\mathrm{k}=200-6=194$

Oleh karena tingkat signifikansinya $0,000<0,05$ dan $\mathrm{f}_{\text {hitung }}>\mathrm{F}_{\text {tabel }}$ $(48,550>2,26)$ sehingga menunjukkan bahwa $\mathrm{H}_{0}$ ditolak dan $\mathrm{H}_{\mathrm{a}}$ diterima yang berarti pengaruh kualitas layanan yang terdiri dari variabel tangible $\left(\mathrm{X}_{1}\right)$, empaty $\left(\mathrm{X}_{2}\right)$, responsiveness $\left(\mathrm{X}_{3}\right)$, reliability $\left(\mathrm{X}_{4}\right)$ dan assurance $\left(\mathrm{X}_{5}\right)$ berpengaruh secara positif dan signifikan terhadap Kepuasan jasa BRT Trans Musi Palembang $(\mathrm{Y})$.

\section{Analisis Regresi Linear Berganda}

Regresi linear berganda adalah uji dengan 2 atau lebih variabel independent digunakan untuk meramal suatu variabel dependent $\mathrm{Y}$ berdasarkan dua atau lebih variabel independent $\left(\mathrm{X}_{1}\right.$ dan $\left.\mathrm{X}_{2}\right)$ dalam suatu persamaan. Berikut adalah hasil pengolahan data menggunakan spss pada Tabel 23. 
Tabel 23

Hasil Analisis Regresi Berganda

Coefficients $^{\text {a }}$

\begin{tabular}{|c|c|c|c|c|c|c|}
\hline \multirow[b]{2}{*}{ Model } & \multicolumn{2}{|c|}{$\begin{array}{l}\text { Unstandardized } \\
\text { Coefficients }\end{array}$} & \multirow{2}{*}{$\begin{array}{c}\begin{array}{c}\text { Standardized } \\
\text { Coefficients }\end{array} \\
\text { Beta }\end{array}$} & \multirow{2}{*}{\multicolumn{2}{|c|}{$\mathbf{t}$}} & \multirow[b]{2}{*}{ Sig. } \\
\hline & B & Std. Error & & & & \\
\hline 1 (Constant) & -3.376 & 1.443 & & & -2.340 & .020 \\
\hline TANGIBLE & .402 & .071 & & .346 & 5.623 & .000 \\
\hline EMPATY & .056 & .071 & & .050 & .801 & .424 \\
\hline RESPONSIVE & .293 & .086 & & .216 & 3.413 & .001 \\
\hline RELIABILITY & .189 & .063 & & .153 & 2.988 & .003 \\
\hline ASSURANCE & .345 & .088 & & .232 & 3.926 & .000 \\
\hline
\end{tabular}

a. Dependent Variable: KEPUASAN

Sumber: Hasil Pengolahan Data, 2018

Dari tabel di atas dapat dilihat hasil persamaan regresi linear berganda sebagai berikut:

Keterangan

$$
Y=a+b_{1} X_{1}+b_{2} X_{2}+b_{3} X_{3}+b_{4} X_{4}+b_{5} X_{5}+e
$$

Y : kepuasan

a $\quad:-3.376$

$\mathrm{b}_{1}, \mathrm{~b}_{2} \quad: 0,402 ; 0,056 ; 0,293 ; 0,189 ; 0,345$

$\mathrm{X}_{1}, \mathrm{X}_{2}, \mathrm{X}_{3}, \mathrm{X}_{4}, \mathrm{X}_{5} \quad$ : tangible,empaty, responsivenes, reliability, assurance

$\mathrm{e} \quad: 1,853$

Nilai-nilai tersebut dimasukkan ke dalam persamaan regresi linear berganda, yaitu:

$Y=-3,376+\left(0,402 X_{1}\right)+\left(0,056 X_{2}\right)+\left(0,293 X_{3}\right)+\left(0,189 X_{4}\right)+\left(0,345 X_{5}\right)$

Persamaan regresi linear berganda dapat dijelaskan sebagai berikut:

a. Nilai konstanta (a) adalah $-3,376$ yang artinya jika tangible,empaty, responsivenes, reliability, dan assurance nilainya adalah 0 maka kepuasan jasa BRT Trans Musi Palembang nilainya sebesar -3,376.

b. Nilai koefisien regresi pada variabel tangible $\left(b_{1}\right)$ bernilai positif yaitu 0,402 yang artinya tangible dapat meningkatkan kepuasan jasa BRT Trans Musi Palembang sebesar 0,402 dengan asumsi satu variabel independen lain nilainya tetap.

c. Nilai koefisien regresi pada variabel empaty $\left(\mathrm{b}_{2}\right)$ bernilai positif yaitu 0,056 yang artinya empaty dapat meningkatkan kepuasan jasa BRT Trans Musi Palembang sebesar 0,056 dengan asumsi satu variabel independen lain nilainya tetap.

d. Nilai koefisien regresi pada variabel responsivenes $\left(b_{3}\right)$ bernilai positif yaitu 0,293 yang artinya responsivenes dapat meningkatkan kepuasan jasa BRT Trans Musi Palembang sebesar 0,293 dengan asumsi satu variabel independen lain nilainya tetap. 
e. Nilai koefisien regresi pada variabel reliability $\left(b_{4}\right)$ bernilai positif yaitu 0,189 yang artinya reliability dapat meningkatkan kepuasan jasa BRT Trans Musi Palembang sebesar 0,189 dengan asumsi satu variabel independen lain nilainya tetap.

f. Nilai koefisien regresi pada variabel assurance $\left(b_{5}\right)$ bernilai positif yaitu 0,345 yang artinya assurance dapat meningkatkan kepuasan jasa BRT Trans Musi Palembang sebesar 0,345 dengan asumsi satu variabel independen lain nilainya tetap.

Dari persamaan regresi di atas dapat dilihat bahwa variable tangible yang menunjukkan pengaruh positif terhadap kepuasan jasa BRT Trans Musi Palembang.

\section{Koefisien Determinan}

Koefisien determinasi $\left(\mathrm{R}^{2}\right)$ pada intinya mengukur seberapa jauh kemampuan model dalam menerangkan variasi variabel dependen.Hasil dari koefisien determinan dapat dilihat pada Tabel 24.

Tabel 24

Hasil Uji Koefisien Determinan

\begin{tabular}{cccccc}
\hline \multicolumn{7}{c}{ Model Summary $^{\mathbf{b}}$} \\
\hline Model & $\mathrm{R}$ & R Square & $\begin{array}{c}\text { Adjusted R } \\
\text { Square }\end{array}$ & $\begin{array}{c}\text { Std. Error of the } \\
\text { Estimate }\end{array}$ & $\begin{array}{c}\text { Durbin- } \\
\text { Watson }\end{array}$ \\
\hline 1 & $.746^{\mathrm{a}}$ & .556 & .544 & 2.113 & 2.061 \\
\hline
\end{tabular}

a. Predictors: (Constant), ASSURANCE, RELIABILITY, EMPATY, TANGIBLE, RESPONSIVE

b. Dependent Variable: KEPUASAN

Sumber: Hasil Pengolahan Data, 2018

Berdasarkan tabel di atas dapat dilihat bahwa kepuasan (Y) jasa BRT Trans Musi Palembang dipengaruhi oleh tangible,empaty, responsivenes, reliability, dan assurance sebesar 54,4\% dan sisanya 45,6\% dipengaruhi oleh faktor lain yang tidak diteliti dalam penelitian ini.

\section{Pengaruh Tangible Terhadap Kepuasan Pelanggan Melalui Pengujian Secara Parsial (Uji T)}

Dari hasil penelitian mengenai variabel tangible didapat hasil bahwa variabel tangible mempengaruhi kepuasan konsumen.Hal ini disebabkan variabel tangible berpengaruh positif terhadap kepuasan konsumen secara individu. Pada hasil pengujian mengenai variabel tangible $\left(\mathrm{X}_{1}\right)$ menghasilkan nilai $\mathrm{t}_{\text {hitung }}$ sebesar 5,623 lebih besar dari $t_{\text {tabel }} 1,9720$ dan nilai signifikansi $0,000<0,05$ serta penelitian ini menghasilkan koefisien positif sebesar 0,402 . Berdasarkan hasil uji t dalam penelitian ini diperoleh hasil bahwa variabel tangible $\left(\mathrm{X}_{1}\right)$ merupakan variabel yang paling berpengaruh secara signifikan. Hal ini sesuai dengan pendapat Kotler dan Keller ( 2012) Tangible yaitu berupa penampilan fisik, peralatan dan berbagai materi komunikasi yang baik. Dengan penampilan fisik yang baik akan membuat konsumen puas dan memutuskan menggunakan layanan BRT Trans Musi Palembang terus menerus. 
Atas dasar uraian diatas diperoleh hipotesis $\mathrm{Ho}_{1}=$ ditolak dan $\mathrm{Ha}_{1}=$ diterima, variabel tangible berpengaruh terhadap kepuasan konsumen pada jasa transpotasi BRT Trans Musi Palembang.

\section{Pengaruh Empaty Terhadap Kepuasan Pelanggan Melalui Pengujian Secara Parsial (Uji T)}

Dari hasil penelitian mengenai variabel empaty, didapat hasil bahwa variabel empaty tidak dapat mempengaruhi kepuasan konsumen. Hal ini disebabkan variabel empaty tidak berpengaruh positif terhadap kepuasan konsumen secara individu. Pada hasil pengujian mengenai variabel empaty $\left(\mathrm{X}_{2}\right)$ menghasilkan nilai $t_{\text {hitung }}$ sebesar 0,801 lebih kecil dari $t_{\text {tabel }} 1,9720$ dan nilai signifikansi $0,424>0,05$ serta penelitian ini menghasilkan koefisien negatif sebesar 0,056. Berdasarkan hasil uji t dalam penelitian ini diperoleh hasil bahwa variabel empaty $\left(\mathrm{X}_{2}\right)$ merupakan variabel yang tidak berpengaruh positif secara parsial.Faktor empaty tidak berpengaruh dimungkinkan kurangnya kepedulian yang dilakukan sopir maupun kondektur BRT Trans Musi Palembang terhadap keluhan-keluhan dan kondisi pelanggan ketika sedang didalam bus dan selama dalam perjalanan.Oleh karena itu kedepan perlu ditingkatkan lagi kepedulian terhadap pelanggan agar penggunaan BRT Trans Musi Palembang dapat memuaskan pelanggan. Menurut Kotler dan Keller (2012) Empathy merupakan kesediaan karyawan dan pengusaha untuk lebih peduli memberikan perhatian secara pribadi kepada pelanggan.

Atas dasar uraian diatas diperoleh hipotesis $\mathrm{Ha}_{2}=$ ditolak dan $\mathrm{Ho}_{2}=$ diterima, variabel empaty tidak berpengaruh terhadap kepuasan konsumen pada jasa transpotasi BRT Trans Musi Palembang.

\section{Pengaruh responsivenes terhadap kepuasan pelanggan melalui pengujian secara parsial (Uji t)}

Dari hasil penelitian mengenai variabel responsivenes didapat hasil bahwa variabel responsivenes mempengaruhi kepuasan konsumen. Hal ini disebabkan variabel responsivenes berpengaruh positif terhadap kepuasan konsumen secara individu. Pada hasil pengujian mengenai variabel responsivenes $\left(\mathrm{X}_{3}\right)$ menghasilkan nilai $t_{\text {hitung }}$ sebesar 3,413 lebih besar dari $t_{\text {tabel }} 1,9720$ dan nilai signifikansi $0,001<0,05$ serta penelitian ini menghasilkan koefisien positif sebesar 0,293. Berdasarkan hasil uji t dalam penelitian ini diperoleh hasil bahwa variabel responsivenes $\left(\mathrm{X}_{3}\right)$ berpengaruh secara signifikan. Hal ini menunjukkan BRT Trans Musi Palembang sudah mampu dalam melayani konsumen dengan cepat tanpa perlu diminta atau mendengar keluhan konsumen terlebih dahulu selama dalam perjalanan menggunakan transportasi bus.Hal serupa sesuai dengan pendapat Kotler dan Keller (2012), Responsiveness merupakan kemauan dari karyawan dan pengusaha untuk membantu pelanggan dan memberikan jasa dengan cepat serta mendengar dan mengatasi keluhan konsumen.

Atas dasar uraian diatas diperoleh hipotesis $\mathrm{Ho}_{3}=$ ditolak dan $\mathrm{Ha}_{3}=$ diterima, variabel responsivenes berpengaruh terhadap kepuasan konsumen pada jasa transpotasi BRT Trans Musi Palembang 


\section{Pengaruh reliability terhadap kepuasan pelanggan melalui pengujian secara parsial (Uji t)}

Dari hasil penelitian mengenai variabel reliability didapat hasil bahwa variabel reliability mempengaruhi kepuasan konsumen. Hal ini disebabkan variabel reliability berpengaruh positif terhadap kepuasan konsumen secara individu. Pada hasil pengujian mengenai variabel reliability $\left(\mathrm{X}_{4}\right)$ menghasilkan nilai $t_{\text {hitung }}$ sebesar 2,988 lebih besar dari $\mathrm{t}_{\text {tabel }} 1,9720$ dan nilai signifikansi $0,003<$ 0,05 serta penelitian ini menghasilkan koefisien positif sebesar 0,189. Berdasarkan hasil uji $\mathrm{t}$ dalam penelitian ini diperoleh hasil bahwa variabel reliability $\left(\mathrm{X}_{4}\right)$ berpengaruh secara signifikan.Hal ini menunjukkan BRT Trans Musi Palembang sudah memberikan kemampuan yang handaldan terpercaya dalam melayani konsumen selama dalam perjalanan menggunakan transportasi bus. Hal serupa sesuai dengan pendapat Kotler dan Keller (2012), Reliability yaitu kemampuan untuk memberikan jasa sesuai dengan yang dijanjikan, terpercaya dan akurat, serta konsisten.

Atas dasar uraian diatas diperoleh hipotesis $\mathrm{Ho}_{4}=$ ditolak dan $\mathrm{Ha}_{4}=$ diterima, variabel reliability berpengaruh terhadap kepuasan konsumen pada jasa transpotasi BRT Trans Musi Palembang

\section{Pengaruh assurance terhadap kepuasan pelanggan melalui pengujian secara parsial (Uji t)}

Dari hasil penelitian mengenai variabel assurance didapat hasil bahwa variabel assurance mempengaruhi kepuasan konsumen.Hal ini disebabkan variabel assurance berpengaruh positif terhadap kepuasan konsumen secara individu. Pada hasil pengujian mengenai variabel assurance $\left(\mathrm{X}_{5}\right)$ menghasilkan nilai $t_{\text {hitung }}$ sebesar 3,926 lebih besar dari $t_{\text {tabel }} 1,9720$ dan nilai signifikansi $0,000<$ 0,05 serta penelitian ini menghasilkan koefisien positif sebesar 0,345. Berdasarkan hasil uji $\mathrm{t}$ dalam penelitian ini diperoleh hasil bahwa variabel assurance $\left(\mathrm{X}_{5}\right)$ berpengaruh secara signifikan. Hal ini menunjukkan BRT Trans Musi Palembang sudah memberikan jaminan dan keyakinan yang lebih kepada konsumen selama dalam perjalanan menggunakan transportasi bus sehingga pelanggan merasa puas.Hal ini sesuai dengan pendapat Kotler dan Keller ( 2012), Assurance yaitu berupa kemampuan karyawan untuk menimbulkan keyakinan dan kepercayaan terhadap janji yang telah dikemukakan kepada konsumen.

Atas dasar uraian diatas diperoleh hipotesis $\mathrm{Ho}_{5}=$ ditolak dan $\mathrm{Ha}_{5}=$ diterima, variabel assurance berpengaruh terhadap kepuasan konsumen pada jasa transpotasi BRT Trans Musi Palembang

\section{Pengaruh tangible, empaty, responsivenes, reliability, dan assurance terhadap kepuasan pelanggan melalui pengujian secara simultan (Uji F)}

Berdasarkan uji hipotesis maka diperoleh hasil uji $\mathrm{F}$ yang menyatakan bahwa variable tangible, empaty, responsivenes, reliability, dan assurance secara bersama-sama (simultan) berpengaruh positif dan signifikan terhadap kepuasan konsumen dengan hasil $\mathrm{F}_{\text {hitung }} 48,550>\mathrm{F}_{\text {tabel }}$ 2,26 dan taraf signifikan 0,000< 0,05. Hal ini menunjukkan kombinasi tangible, empaty, responsivenes, reliability, dan assurance yang dilakukan bersama-sama (simultan) akan meningkatkan kepuasan konsumen dengan menggunakan jasa BRT Trans Musi Palembang. 
Menurut Kotler dan Keller (2009) kepuasan (satisfaction) adalah perasaan senang atau kecewa seseorang yang timbul karena membandingkan kinerja yang telah dipersepsikan produk (atau hasil) terhadap ekspektasi mereka. Dengan memberikan layanan yang berkualitas membuat konsumen menjadi puas. Hal ini sesuai dengan pendapat Tjiptono (2011) yaitu Pelayanan adalah tingkat keunggulan yang diharapkan dan pengendalian atas tingkat keunggulan tersebut untuk memenuhi keinginan pelanggan.

Hasil penelitian ini sesuai dengan hasil penelitian sebelumnya seperti penelitian yang dilakukan oleh Veronica Diona dan Supriyono (2016) yang berjudul Pengaruh Kualitas Pelayanan Terhadap Kepuasan Konsumen Jasa Transportasi Kereta Api Indonesia (KAI) Daerah Operasi 6 Yogyakarta. Dimana hasil uji $\mathrm{F}$ menunjukkan bahwa variabel tangible, reliability, responsiveness, assurance,dan emphaty berpengaruh secara simultan terhadap kepuasan penumpang dengan nilai $\mathrm{F}$ hitung sebesar 26,013 dengan signifikansi 0,000. Hasil penelitian menunjukkan $55,8 \%$ variasi variabel kepuasan penumpang dapat dijelaskan oleh variabel tangible, reliability, responsiveness, assurance, emphaty. Hasil penelitian ini juga sesuai dengan penelitian Arifuddin, Umardhana (2008) dengan judul Analisis pelayanan yang diberikan oleh Bus Trans Jogja terhadap kepuasan pelanggan ditinjau dari dimensi kualitas jasa.Hasil olah data menunjukkan hasil yang signifikan antara kepuasan pelanggan dan dimensi kualitas jasa baik pada pengukuran secara terpisah maupun secara simultan.

Atas dasar uraian diatas diperoleh hipotesis $\mathrm{Ho}_{6}=$ ditolak dan $\mathrm{Ha}_{6}=$ diterima, variabel tangible $\left(\mathrm{X}_{1}\right)$, empaty $\left(\mathrm{X}_{2}\right)$, responsiveness $\left(\mathrm{X}_{3}\right)$, reliability $\left(\mathrm{X}_{4}\right)$, dan assurance $\left(\mathrm{X}_{5}\right)$ secara bersama-sama (simultan) berpengaruh positif terhadap kepuasan konsumen pada jasa transpotasi BRT Trans Musi Palembang

\section{KESIMPULAN DAN IMPLIKASI}

1. Kualitas pelayanan yang terdiri dari variabel tangible, variabel empaty, variabel responsivenes, variabel reliability, dan variabel assurance sangat berpengaruh terhadap kepuasan konsumen pada jasa BRT Trans Musi Palembang.

2. Dalam penelitian ini variabel tangible yang paling dominan terhadap kepuasan pe konsumen pada jasa BRT Trans Musi Palembang.

3. Variabel empaty pada penelitian ini tidak mempengaruhi kepuasan konsumen pada jasa BRT Trans Musi Palembang.

4. Penelitian ini diharapkan mampu memberikan pemahaman dan informasi tambahan dalam mengambil kebijakan bagi manajemen BRT Trans Musi Palembang untuk meningkatkan kepuasan pelanggan sebagai pengguna jasa transportasi.

5. Penelitian ini masih terbatas dengan jumlah sampelnya yaitu 200 responden dan variabel penelitian juga terbatas hanya pada kualitas layanan yang terdiri variabel tangible, empaty, responsivenes, reliability, dan assurance.

6. Disarankan untuk penelitian mendatang jumlah sampel yang digunakan bisa lebih banyak lagi agar mendapatkan hasil yang lebih baik dan dapat menggunakan variabel lainnya seperti harga dan emosi untuk mengukur kepuasan konsumen pengguna jasa BRT Trans Musi Palembang. 


\section{DAFTAR PUSTAKA}

Arifuddin, Umardhana. 2008. Analisis Pelayanan yang Diberikan oleh Bus Transjogja terhadap Kepuasan Pelanggan Ditinjau dari Dimens Kualitas Jasa. Kebijakan Pendidikan. UNY

BRT Trans Musi, http://sp2j.co.id/nbrt/.

Fandy, Tjiptono. 2009. Strategi Pemasaran Jasa. CV. Andi:Yogyakarta

Fandy, Tjiptono. 2011. Service Management Mewujudkan Layanan Prima. Edisi 2.Yogyakarta: Andi.

Hair et al., 1998. Multivariate Data Analysis, Fifth Edition, Prentice Hall, Upper Saddle River :New Jersey.

Kotler dan Keller. 2009. Manajemen Pemasaran. Jilid I. Edisi ke 13 Erlanga Jakarta

Kotler, dan Keller. 2012. Manajemen Pemasaran.Edisi 12. Jakarta: Erlangga

Kotler,Philip and Gary Armstrong. 2012. Prinsip-prinsip Pemasaran. Edisi 13.Jilid 1. Jakarta: Erlangga.

Sugiyono. 2010. Metode Penelitian Kuantitatif Kualitatif \& RND. Bandung :Alfabeta

Sugiyono. 2012. Metode Penelitian Kuantitatif, Kualitatif dan R\&D, Alfabeta, Bandung.

Sugiyono. 2013. Metode Penelitian Pendidikan Pendekatan Kuantitatif, Kualitatif dan $\boldsymbol{R} \& \boldsymbol{D}$, Alfabeta, Bandung.

Veronica Diona dan Supriyono. 2016. Pengaruh Kualitas Pelayanan Terhadap Kepuasan Konsumen Jasa Transportasi Kereta Api Indonesia (KAI) Daerah Operasi 6 Yogyakarta, Berkalah Ilmiah ADAVANCE Vol.3 No.1 Maret 2016 STIE AUB Surakarta. 